\title{
Experience of the Project Approach to Non-Standard Forms of Youth Employment 'Volunteering' and 'Voluntourism' (Based on the Example of Public Authorities in Mariupol)
}

\author{
Galina A. Krapivina \\ Priazovskyi State Technical University \\ 87500, 7 Universitetska Str., Mariupol, Ukraine \\ Milana V. Pakhomova \\ Ukrainian State Employment Service Training Institute \\ 03038, 17 Novovokzalna Str., Kyiv, Ukraine \\ Nataliya P. Boretskaya \\ Kyiv National University of Technology and Design \\ 01011, 2 Nemirovicha-Danchenko Str., Kyiv, Ukraine \\ Olena V. Chasnikova \\ Institute of Pedagogy of the National Academy of Pedagogical Sciences of Ukraine \\ 04053, 52-D Sichovykh Striltsiv Str., Kyiv, Ukraine \\ Yuliya O. Burtseva \\ Donetsk Regional In-Service Teacher Training Institute \\ 84300, 47 Vasyl Stus Str., Kramatorsk, Ukraine

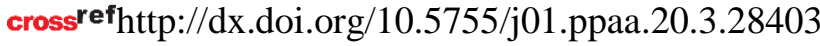

\begin{abstract}
The topic of the study is especially relevant because of the non-standard form of employment (NFE) 'volunteering' has acquired across the global. Similarly, NFE 'voluntourism' has recently been acquiring the form of a social movement and the development of mechanisms for public administration of these activities is far from complete. The aim of the article is to summarise the world experience of the project approach of public authorities to youth policy and the introduction of NFE of youth 'volunteering', as well as to analyse the experience of the micro-project approach of public authorities in Mariupol, Ukraine. The study is based on a comprehensive and systematic approach to public management of youth employment and uses methods to describe, summarise, analyse and synthesise the results of observations and experiments. The generalisation of the world experience of the project approach of public authorities to the introduction of non-standard forms of youth employment 'volunteering' and 'voluntourism' and the modern experience of its use is supported by UNESCO, which allows expanding its scope. It established that experience of the project approach of public authorities on creation of NFE 'volunteering' in the city of Mariupol, Ukraine, can be considered as innovative technology of information education. Thus, the project approach of public authorities with the use of NFE 'volunteering' and 'voluntourism' plays a specific useful role in professional and life situations of young people and allows them to perform social functions of professional, community and personal goals and competencies.
\end{abstract}

Keywords: project approach, social development, territorial communities, public administration

Raktažodžiai: projektas, socialinè plètra, teritorinès bendruomenès, viešasis administravimas 


\section{Introduction}

The public authorities of many countries of the world paid great attention to the non-standard forms of employment (NFE) of youth. Thus, in France, the construction of community centres for young people began after World War II. The public authorities set them the task of uniting and establishing contacts between people of different origins and different professions for the socially effective use of free time. These houses of culture in France were not part of the infrastructure of local communities. These were separate institutions that organised and coordinated the involvement of free time of young people in their area (Marchenko, 2018; 2019). A feature of the project approach of public authorities to youth institutions in Bulgaria was compliance with the scale of the country due to the lack of gigantism and ostentation in the territorial communities. In Germany, the programme approach of public authorities to the creation of children's and youth institutions was based on their classification into centralised youth clubs, youth sections at houses of culture and educational institutions, pioneer houses, houses of science and technology for schoolchildren, gyms, complexes and zones of rest. In Japan, the programmatic approach has led public authorities to decide to move youth centres outside the territorial community (e.g., a youth complex in Shiga Prefecture, a youth centre on the island of Okinawa). In many cities in the United States, Canada, the United Kingdom and other countries, youth centres (according to the programme approach of public authorities) are created at university complexes. The 'Organisation of Young Friends of Nature' of Austria and the 'World Association of Young Christian Women' are the most common programme approach of public authorities to the organisation and forms of work with youth in the world (Table 1).

Table 1. Features of the project approach of public authorities to the NFE of youth'"volunteering' in the world

\begin{tabular}{|c|c|c|c|}
\hline COUNTRY & TERMS & THE MAIN TASK & PROGRAM OF ACTIVITIES \\
\hline France & After 1945 & $\begin{array}{l}\text { Socially effective use } \\
\text { of youth free time }\end{array}$ & $\begin{array}{c}\text { Entertainment, physical, volunteering, } \\
\text { intellectual, artistic activities, } \\
\text { information, performances, travel, } \\
\text { public service }\end{array}$ \\
\hline Bulgaria & & $\begin{array}{c}\text { Adherence to the scale } \\
\text { of the country }\end{array}$ & $\begin{array}{c}\text { Casual process of using free time and } \\
\text { determining the interests of young } \\
\text { people }\end{array}$ \\
\hline Germany & & $\begin{array}{c}\text { Classification of } \\
\text { children's and youth } \\
\text { institutions } \\
\end{array}$ & $\begin{array}{c}\text { Combination of entertainment, } \\
\text { physical, technical activities, } \\
\text { information, travel, public services }\end{array}$ \\
\hline Japan & & $\begin{array}{l}\text { Removal of youth } \\
\text { centres outside the } \\
\text { territorial community }\end{array}$ & $\begin{array}{l}\text { Attracting young people to spend their } \\
\text { free time through entertainment, } \\
\text { educational and training functions }\end{array}$ \\
\hline $\begin{array}{l}\text { Austria, 'Organisation of } \\
\text { Young Friends of Nature' }\end{array}$ & $\begin{array}{c}\text { Established in } \\
1895 . \\
\text { Banned in } 1934 \text { by } \\
\text { the Nazis. } \\
\text { Restored in } 1945 \\
\end{array}$ & $\begin{array}{l}\text { Territorial principle } \\
\text { according to the } \\
\text { administrative division } \\
\text { of the country }\end{array}$ & $\begin{array}{c}\text { Organisation of youth leisure as an } \\
\text { alternative to the leisure industry and } \\
\text { more }\end{array}$ \\
\hline $\begin{array}{c}\text { USA, Canada, Great } \\
\text { Britain and other countries }\end{array}$ & & & $\begin{array}{l}\text { Combination with socio-cultural } \\
\text { centres of university complexes }\end{array}$ \\
\hline $\begin{array}{l}\text { International Confessional } \\
\text { Organisation 'World } \\
\text { Association of Young } \\
\text { Christian Women' }\end{array}$ & London, 1894 & $\begin{array}{l}\text { Development of mutual } \\
\text { understanding and } \\
\text { cooperation at the } \\
\text { national and } \\
\text { international level }\end{array}$ & $\begin{array}{c}\text { (NFE) 'volunteering' in developing } \\
\text { countries; work among refugees and } \\
\text { immigrants }\end{array}$ \\
\hline Former USSR & 1925 & $\begin{array}{l}\text { Work with young } \\
\text { people in youth } \\
\text { sections at houses and } \\
\text { palaces of culture of } \\
\text { general type }\end{array}$ & \\
\hline
\end{tabular}


Today the 'Organisation of Young Friends of Nature' of Austria has 55000 members aged 6 to 25 . The organisation is managed by public authorities at the federal and state levels. Their main tasks are as follows: involvement of young people in public activities, primarily in nature protection; advising persons who refuse to perform military service; management of sections and circles on mountaineering, orienteering, etc. In turn, the World Association of Young Christian Women is a large international confessional project approach of public authorities to create an organisation that works with young women. It was founded to spread and strengthen the influence of Protestantism among girls and young women. Official goals of the organisation involve the dissemination of constructive relations with international associations, both non-governmental and interstate; protection of human rights, in particular the rights of children; promoting the unification of women and girls into universal global cooperation based on the principles of Christian unity. The association unites national organisations of 84 countries, the programme approach of public authorities to the activity of which is based on the club form of work. Organisations pay special attention to nonstandard forms of employment (NFE) projects and volunteering in developing countries. It has a consultative status with UNESCO as represented in the Office of the UN High Commissioner.

The aim of the article is to summarise the world experience of the project approach of public authorities to youth policy and to introduce NFE of youth 'volunteering' as well as analyse the experience of micro-project approach of public authorities in Mariupol, Ukraine. The study is based on a comprehensive and systematic approach to public management of youth employment and uses methods to describe, summarise, analyse and synthesise the results of observations and experiments. These methods make it possible to reveal skills acquired through non-standard forms of youth employment 'volunteering' and 'voluntourism'. The participation in NFE 'volunteering' and 'voluntourism' is investigated both through observations and through asking young people to participate. The basic method for formulating indicators is posing questions that aim at identifying the core aspects or characteristics of the subject matter handled. In terms of the data analysis method, the authors have provided the results of an open survey (interview with a sample of 30 people) of leaders and activists of public and charitable organisations of Mariupol.

\section{The Development of 'Volunteering' and 'Voluntourism'}

In the former USSR, public authorities in 1925 approved youth sections at houses and palaces of culture of general type as the main form of work with youth. That is, public authorities implement the processes of public using leisure time of youth with a project approach. This leads to the emergence of multifunctional cultural centres in local communities and the problem of organising youth leisure. UNESCO has supported youth labour camps since its inception in 1946. Under the auspices of UNESCO, a non-profit organisation the Coordinating Commission on Labour Camps (later the Coordinating Commission for International Voluntary Service) was established in 1948. Until the early 1960s, the decision of the General Conference and the Executive Directorate on educational programs concerned only the support of international labour camps because of their great contribution to international understanding.

At the sessions of the General Conference in 1972 and 1974, UNESCO recommended that public authorities promote national and international volunteering and provide support to youth nongovernmental organisations involved. From 1976 to 1995, meetings, training seminars and internships were organised with the involvement of grants and contracts of the Coordinating Commission for International Voluntary Service with several governmental and non-governmental volunteer organisations and through contacts with international organisations: Volunteers of the United Nations and the Council of Europe. In 1995, the United Nations General Assembly adopted the World Youth Program until 2000 and beyond, and the UN General Conference decided that youth is a target group for UNESCO.

A UNESCO Central Secretariat has also been set up to develop a comprehensive volunteer program for all ages. These changes have significantly affected the way in which the Secretariat, in close cooperation with the Coordinating Commission for the International Voluntary Service, has 
organised the activities of the UNESCO Youth Volunteer Program. However, the UNESCO volunteer corps was not established and the volunteer committee was abolished in 1997. However, in 1998, the Directorate-General reoriented and strengthened youth programs and organisational structures based on a project approach. It was decided that special attention should be paid to volunteer work as an indispensable means of mobilising young people and providing NFE 'volunteering', which was entrusted to the Youth Coordinating Council. The Council addressed this issue in constant consultations with young people, youth and non-governmental and other partner organisations. The non-standard form of employment (NFE) 'volunteering' and NFE 'voluntourism' have acquired the form of a social movement relatively recently and the development of mechanisms for public administration of these activities is far from complete (Park et al., 2019; Pozzi et al., 2019; Vecina and Marzana, 2019). Given this context, the study of the state and status of the volunteer movement is especially relevant for Ukraine.

2014 was a significant year in the development of volunteerism in Ukraine as it gave a powerful impetus for the formation of a number of volunteer movements, which have become a vivid example of the high level of civic consciousness of Ukrainians and their ability to self-organise (Umanska, 2021). Youth volunteering is reflected in the Concept of the State Target Social Programme 'Youth of Ukraine 2016-2020' from two perspectives: as a tool for non-formal education (Priority 3) and as secondary employment (Priority 4). Priority 3 covers the issues of non-formal learning through the implementation of measures aimed at the acquisition of knowledge, skills and other competences outside the education system, through participation in volunteering activities. This covers the following tools: Youth Worker Programme, development of youth centres, youth camps, youth information and e-learning platforms, youth passport (as a tool for recognition). Priority 4 covers the creation of conditions and activities aimed at youth employment (provision of primary and secondary employment and self-employment of youth). Volunteering is reflected as one of the tools for secondary employment (Contribution of Non-programme Countries..., 2018). Representatives of volunteer organisations are involved in clothing, food and medical supplies, some of them are now working in the Departments of the Ministry of Defense responsible for supplying the Armed Forces of Ukraine. Therefore, at the moment the volunteer movement in Ukraine is a manifestation of a certain maturity of civil society, it supplements the functions of state bodies, contributes to the stabilization and regulation of social relations under the conditions of decentralization (Umanska, 2021).

The draft law of Ukraine 'On Youth' (2015) considers volunteering as a secondary employment of a young person, and the additional knowledge and skills gained in selfless work are perceived as one of the components of professional orientation and self-development of a young person. For students, this is a significant motivation and opportunity to obtain certain preferences in employment in enterprises and in the organisation of both public and private property, in local governments as well as in the creation and development of their own business (Tashkinova, 2018). It is in the interests of public authorities to encourage NFE 'volunteering' among young people, to support various volunteer projects and social entrepreneurship (and social entrepreneurs in particular) which provide conditions for youth participation in volunteering. That is, modern public authorities have long been dominated by the understanding that the volunteer movement (as part of the NFZ 'volunteering' and 'voluntourism') is able to promote the competitiveness and career growth of volunteers. Ukraine is no exception. The Law of Ukraine 'On Education' No. 2145-VIII (2017) distinguish between non-formal education, which does not provide obtaining educational qualifications by level of education, and informal education, "which provides self-organised acquisition of certain competencies during daily activities related to professional, social or other activities, family or leisure'. Thus, informal and non-formal education are very closely linked to NFE 'volunteering' and 'voluntourism'.

Today, more and more volunteers unselfishly do socially important work. In Mariupol, volunteer activities are presented within the framework of the activities of non-governmental organisations and charitable foundations. For example, 'Caritas Mariupol' is a non-profit charitable 
organisation, which aims to provide social assistance and support to the neediest population of Ukraine regardless of their nationality or religion. Currently, the 'Caritas' specialists are working on about 10 social and humanitarian projects with the support of international charities and ministries of development of many European countries. There is a 'School of Volunteering' in Mariupol, which was established by the city branch of the Ukrainian Leadership Academy. It was held in the format of online classes. Volunteers worked more than 100 hours, participating in the work of such organisations as 'Caritas', 'Red Cross', 'Burchik' and 'Old Age for Joy'. They independently organised six volunteer initiatives. As a result, about 20 participants were trained who will not only be able to volunteer professionally, but also to implement their own projects and initiatives.

The purpose of the micro-project of public authorities of Mariupol, Ukraine, that was implemented at the Azov State Technical University was to create educational technology for NFE 'volunteering', through which motivated and socially active students on a voluntary basis were able to implement community initiatives, develop their competencies as future professionals and conscious and responsible citizens of the state (Boretskaya et al., 2014). In accordance with this goal, the project of public authorities set the following tasks: 1) to create motivation that would direct socially active youth to join the NFE 'volunteering'; 2) to organise communication with as many project participants as possible; 3 ) to create conditions for students to adapt the knowledge and skills acquired in higher education, improve their professional competencies; 4) to form a database of socially active youth for public authorities, to raise their level of awareness through various training sessions; to draw the attention of stakeholders to potential workers with an active life and social position.

At the request of the public authorities of the city of Mariupol, the study 'City through the eyes of students' was conducted. 486 full-time students from various universities in the city of Mariupol, Ukraine, participated in it. The study was representative and reflected the general population on a number of grounds: institution, faculty, course of study. The error was $3 \%$. The results of the study showed that $63 \%$ of respondents wanted to participate in city life; $33 \%$ of respondents were interested in working in public authorities; $64 \%$ knew the problems of the territorial community and the directions of their solution (the priorities were ecology, urban transport, the state of roads, improving the living standards of the population as a whole); $58 \%$ wanted to have a greater practical component in their education; 85\% received information and communicated via the Internet and social networks; 99\% used a mobile phone, including mobile applications (Krapivina, 2010) (Krapivina, 2010) (Table 2).

\section{Table 2. The results of the study 'City through the eyes of students' (Mariupol, Ukraine)}

\begin{tabular}{|l|c|}
\hline \multicolumn{1}{|c|}{ SURVEY RESULTS } & NUMBER OF RESPONDENTS, $\%$ \\
\hline Want to take part in the life of the city & 63 \\
\hline Interested in working in public power & 33 \\
\hline $\begin{array}{l}\text { Know the problems of the territorial community and the directions of their } \\
\text { solution }\end{array}$ & 64 \\
\hline Want to have a greater practical component in their education & 58 \\
\hline Receive information and communicate via the Internet and social networks & 85 \\
\hline Use a mobile phone and mobile applications & 99 \\
\hline
\end{tabular}

Source: Authors.

Afterwards the students founded the NGO 'Future of Mariupol' whose members in cooperation with universities and with the support of the Mariupol City Council developed a NFE project ' 100 hours of volunteering'. The project aimed at providing free public goods to people. The project was supported by United States Agency for International Development (USAID). The main idea of the project was to build a platform for interaction of all NFEs 'volunteering', youth student organisations, social initiatives with the public authorities of the city and organisations that need youth support and initiative. 


\section{Features of Formation of Social Initiative}

The preparatory stage of the micro-project (October-December 2017) consisted, first, of an in-depth open survey (an interview with a sample of 30 people) of leaders and activists of public and charitable organisations of Mariupol, namely: representatives of the Red Cross, charitable foundations 'Adra', 'Our Mariupol', 'Epoch of Mercy', 'Caritas-Ukraine', Children's Fund and others. The purpose of the preparatory stage was to identify the motivation, achievements and problems of NFE 'volunteering' in the city of Mariupol. The analysis of sociological research has revealed rather serious activisation of volunteer (in particular youth) movements in the city. During the main stage of the microproject students majoring in Social Work of the Faculty of Social Sciences and Humanities of the Pre-Azov State Technical University (PSTU) founded the public organisation 'Future of Mariupol'. Members of this organisation in cooperation with the administration of PSTU and with the support of Mariupol city council developed the project ' 100 hours of volunteering'. The website www.100hov.org.ua became a key tool for involving students and active youth in the implementation of social initiatives through NFE 'volunteering'. The main idea of the project was to build a platform for interaction of all NFE 'volunteering', youth student organisations, social initiatives with public administration and organisations that need youth support and initiative. Everyone had the opportunity to take part in the project. A person could volunteer to register on the site on his own or with the help of the project team. After that, a volunteer profile was created, which took into account working hours and performance indicators.

The site was filled with applications from public authorities, public and other organisations as well as city residents who needed help, electronically or by phone after registration (Speckesser et al., 2019). Upon registration, a customer was acquainted with a brief history of NFE 'volunteering' in a comic/ concice?? format, with information on support for application deadlines and competencies as well as possible amounts of assistance by volunteers. After the volunteers checked the application, the customer went to the location. Each volunteer had the opportunity to find their tasks on a map with active locations. The informational structure of tasks for volunteers contained the following indicators: a customer; place and time of execution; task description; the amount (hours) charged to a volunteer for its implementation; task complexity; equipment needed to perform the task; number of participants. Tasks for volunteers were classified according to the following factors: human resources (individual, team), level of difficulty (junior, easy, medium, difficult, professional) and areas of activity (social sphere, culture, sports, tourism, education, landscaping, medicine, ecology). Within the project, a system of evaluation of the quality of the volunteer's work and tasks of the customer was formed. According to the quality of the volunteer's work, his/her trust rating was formed. The system also provided comments from customers about the volunteer's work. In turn, the volunteer also had the opportunity to comment on the task.

The project was presented at Donetsk State University of Management, Mariupol State University, Donetsk Law Institute, at the faculties of PSTU, in the city council, in the department of social protection. The PSTU website, social networks, local official and information sites were used to promote the project. Volunteers took part in citywide projects 'Book communal work', 'Europe Day', 'Mariupolfest' and others and functioned as translators, guides, coordinators, etc.; they recorded texts of audio books for the visually impaired, installed software on private computers, organised holiday for children, cleaned the city, planted trees, conducted surveys for opinion polls. The public authority project began to be implemented in January 2018. Today, a base of 300 volunteers (students, schoolchildren, active youth) with different numbers of accumulated hours of volunteer work has been created. The most active volunteers took part in masterclasses and specialised training sessions with experienced specialists in volunteer projects in other cities, where they could gain knowledge in psychology, communication, creative thinking and decision making. This made it possible to start a dialogue between public authorities and youth, which helped increase the level of youth loyalty to the government.

Volunteers who worked in the project ' 100 hours of volunteering' received motivational prizes and a certificate signed by the mayor. This gives them a certain advantage in employment in 
utilities and public authorities of the city, which was a serious motivation to participate in the NFE 'volunteering'. The spread of the micro-project was the initiative of the university to provide students with foreign practice in institutions of accommodation in Poland, Bulgaria and Turkey on the basis of NFE 'voluntourism'. Currently, 28 students have taken part in the project. The results of volunteer activities aroused great interest in the local community. Even though the COVID-19 pandemic has suspended this process, hopefully, it will not have a long-lasting effect. With the help of projects, volunteers develop an understanding that participation in NFE 'volunteering' and 'voluntourism' is a unique opportunity to prove themselves as future specialists, develop competencies in various fields, determine the direction of their future careers, form professional and social and national ties for professional growth and development. The public authorities have received a database of active young professionals who have some practical experience, are socially motivated, communicative, able to work in a team, creative, i.e.; young people who are a potential elite of the city community.

According to G.A. Krapivina (2019), the training received in these types of education is already defined by many stakeholders as comparable to the experience of the labour market and can make a significant contribution to the formation of a qualified professional with an active life and professional position and intercultural communication skills. The impact of the project approach of public authorities on the student volunteer movement is the need to study the mechanism of transmission of social values, which can be considered basic for all people and at all times. Such values include NFE 'volunteering' and 'voluntourism'. They are an important component of selfrealisation of students' own creative potential and a useful means of acquiring professional skills and abilities (Marchenko and Krapivina, 2020). In addition, the clarity of the role, level of time commitment, regular feedback, recognition of effort and strong networks for on-going support are important strategies to facilitate volunteer retention (Stathi et al., 2021). Understanding the extent and depth of the volunteers' experience will help to prevent the undervaluing of their contribution and increase the impact of their involvement (Scott et al., 2021).

\section{Conclusion}

The article presents brief characteristics of project campaigns of public authorities of different countries to the use of non-standard forms of youth employment 'volunteering' and 'voluntourism'. The main conclusions and results of the study are as follows:

1. Globally, public authorities widely implement the processes of society's use of young people's free time using a project approach;

2. The project approach of public authorities to the use of youth NFE has existed for more than 100 years;

3. The use of the project approach causes the emergence of multifunctional houses for young people in local communities and the problem of organising youth leisure;

4. Experience of the project approach of public authorities on creation of NFE 'volunteering' in the city of Mariupol, Ukraine, can be considered as innovative technology of information education;

5. The project approach of public authorities with the use of NFE 'volunteering' and 'voluntourism' plays a specific useful role in professional and life situations of young people and allows them to perform social functions of professional, community andand personal goals and competencies.

\section{References}

1. Boretskaya, N.P., Bagdasarova, D.G., and Krapivina, G.O. 2014. "Mechanisms of motivation and evaluation of work of service enterprises". Socio-Labor Relations: Theory and Practice, 2(8): 311-318.

2. Contribution of Non-programme Countries to EU Youth Wiki. Ukraine. Chapter II: Voluntary Activities. 2018. https://pjp-eu.coe.int/documents/42128013/47262475/YouthWiki_volunteering_Ukraine.pdf [21-01-10].

3. Draft Law of Ukraine No. 3621 "On Youth" on December $10,2015$. http://w1.c1.rada.gov.ua/pls/zweb2/webproc4_1?pf3511=57368 [20-12-03]. 
4. Krapivina, G.A. 2010. "Human resources and their motivation in volunteering". Bulletin of the Lviv Institute of Economics and Tourism, 5: 107-109.

5. Krapivina, G.A. 2019. "Mechanisms of state management of work motivation in non-standard forms of employment (on the example of volunteering and volunteerism)". Reporter of the Priazovskyi State Technical University, 36: 240-249.

6. Law of Ukraine No. 2145-VIII “On education” on May 09, 2017. https://zakon.rada.gov.ua/laws/show/214519\#Text [20-12-03].

7. Marchenko, I., and Krapivina, G.A. 2020. "Non-standard form of employment "volunteering": the experience of innovative technologies in the educational space (on the example of training qualified professionals for public authorities of Mariupol". In Scientific and Practical Support of Public Services in Decentralization, 365-370. Kyiv: ArtEk.

8. Marchenko, I.F. 2018. "Volunteering - as an innovative component in the formation of professional and social competencies of future leaders". In Modern IEM: Drivers of Success and Development Challenges, 99-103. Dnipro: Dnipro National University named after Oles Honchar.

9. Marchenko, I.F. 2019. "Volunteering as an educational technology for the formation of professional and civic competencies of future professionals". In Innovative University and Leadership: Project and Microprojects - III, 289-299. Warsaw: Wydzial "Artes Liberales" UW.

10. Park, S., Choi, B., Choi, C., Kang, J.M., and Lee, J. 2019. "Relationship between education, leisure activities, and cognitive functions in older adults". Aging and Mental Health, 23(12): 1651-1660.

11. Pozzi, M., Meneghini, A.M., and Marta, E. 2019. "Does volunteering at events motivate repeat engagement in voluntary service? The case of young adult volunteers at EXPO Milan 2015”. Testing, Psychometrics, Methodology in Applied Psychology, 26(4 Special Issue): 541-560.

12. Scott, R., Goossensen, A., Payne, S., and Pelttari, L. 2021. "What it means to be a palliative care volunteer in eight European countries: a qualitative analysis of accounts of volunteering". Scandinavian Journal of Caring Sciences, 35(1): 170-177. doi: $10.1111 / \mathrm{scs} .12832$

13. Speckesser, S.S., Gonzalez Carreras, F.J., and Kirchner Sala, L. 2019. “Active labour market policies for young people and youth unemployment: an analysis based on aggregate data". International Journal of Manpower, 40(8): 1510-1534.

14. Stathi, A., Withall, J., Agyapong-Badu, S., Barrett, E., Kritz, M., Wills, D., Thogersen-Ntoumani, C., and Fox, K.R. 2021. "Mobilising people as assets for active ageing promotion: a multi-stakeholder perspective on peer volunteering initiatives". BMC Public Health, 21(1):150. doi: 10.1186/s12889-020-10136-2

15. Tashkinova, O.A. 2018. "Social well-being of student youth: methodological and methodological aspects of definition". In University Science 2018. Theses of the International Scientific and Technical Conference in 3 vols., May 23-24, 2018, Mariupol, Ukraine, vol. 3, 110-112. Mariupol: PSTU.

16. Umanska, O. 2021. "Volunteering in Ukraine". https://uwcfoundation.com/en/blagotvoritelnost-vukraine/volontyorstvo-v-ukraine [21-01-10].

17. Vecina, M.L., and Marzana, D. 2019. "Motivations for volunteering: Do motivation questionnaires measure what actually drives volunteers?” Testing, Psychometrics, Methodology in Applied Psychology, 26(4 Special Issue): 573587.

\section{Galina A. Krapivina, Milana V. Pakhomova, Nataliya P. Boretskaya, Olena V. Chasnikova, Yuliya O. Burtseva}

\section{Projekto metodo patirtis taikant nestandartinę jaunimo užimtumo formą ,savanoryste grịstas turizmas": Mariupolio viešųjų institucijų pavyzdys \\ Anotacija}

Tyrimo tema aktuali, nes nestandartinè jaunimo užimtumo forma „Savanoryste grịstas turizmas" populiarèja visame pasaulyje ir tampa socialiniu judejjimu. Vis dèlto šios veiklos viešojo administravimo mechanizmų kūrimas toli gražu nėra baigtas. Straipsnio tikslas - apibendrinti pasaulinę patirtį, iggyvendinant valstybinių institucijų požiūrị ị jaunimo politiką ir nestandartinių jaunimo užimtumo formų ịvedimą i jaunimo savanorystę, taip pat išanalizuoti Mariupolio (Ukraina) valdžios institucijų projektinio požiūrio patirtį. Tyrimas grindžiamas visapusišku ir sisteminiu požiūriu i jaunimo užimtumo viešajị valdymą; tyrime naudoti metodai stebejjimų ir eksperimentų rezultatams apibūdinti, apibendrinti, analizuoti ir sintezuoti. UNESCO remia valdžios institucijų projektini požiūrị i nestandartinę jaunimo užimtumo formą „Savanoryste grịstas turizmas“ ir šiuolaikinę jos naudojimo patirtį; tai leidžia išplèsti šio požiūrio taikymo sritį. Tyrimas nustatè, kad valdžios institucijų projektinio požiūrio ị nestandartinę jaunimo užimtumo formą „Savanoryste 
grịstas turizmas" Ukrainoje, Mariupolyje, patirtis gali būti laikoma novatoriška informacinio švietimo technologija. Taigi, valdžios institucijų projektinis požiūris taikant tokią nestandartinę jaunimo užimtumo formą atlieka ypatingai naudingą vaidmenį jaunų žmonių profesinèse ir gyvenimo situacijose ir leidžia jiems atlikti socialines funkcijas, susijusias su profesiniais, bendruomenès ir asmeniniais tikslais bei kompetencijomis.

Galina A. Krapivina - PhD in Public Administration, Assistant Professor at the Department of Tourism, Priazovskyi State Technical University, Mariupol, Ukraine.

E-mail: ga.krapivina@tanu.pro

Milana V. Pakhomova - PhD in Public Administration, Associate Professor at the Department of Public Administration and Management, Ukrainian State Employment Service Training Institute, Kyiv, Ukraine.

E-mail: mila-pakhomova@uohk.com

Nataliya P. Boretskaya - Full Doctor in Economics, Professor at the Department of Economics and Service, Kyiv National University of Technology and Design, Kyiv, Ukraine.

E-mail: nat.boretskaya@ust-hk.com

Olena V. Chasnikova - PhD in Pedagogy, Senior Researcher at the Department of Geography and Economics, Institute of Pedagogy of the National Academy of Pedagogical Sciences of Ukraine, Kyiv, Ukraine.

E-mail: ochasnikova@uohk.com

Yuliya O. Burtseva - PhD in Pedagogy, Acting Rector at the Department of Administration, Donetsk Regional In-Service Teacher Training Institute, Kramatorsk, Ukraine.

E-mail: yu.burtseva@tanu.pro

Galina A. Krapivina - Viešojo administravimo mokslų daktarè, docentė, Turizmo katedra, Valstybinis Priazovski technikos universitetas, Mariupolis, Ukraina.

El. paštas: ga.krapivina@tanu.pro

Milana V. Pakhomova - Viešojo administravimo mokslų daktarè, docente, Viešojo administravimo ir vadybos katedros, Ukrainos valstybinio užimtumo tarnybos institutas, Kijevas, Ukraina.

El. paštas: mila-pakhomova@uohk.com

Nataliya P. Boretskaya - Ekonomikos mokslų daktarè, profesorè, Ekonomikos katedra, Kijevo valstybinio technologijos ir dizaino universitetas, Kijevas, Ukraina.

El. paštas: nat.boretskaya@ust-hk.com

Olena V. Chasnikova - Pedagogikos mokslų daktarè, vyrsenioji tyrèja, Ukrainos valstybinès pedagogikos mokslų akademijos Pedagogikos institutas, Kijevas, Ukraina.

El. paštas: ochasnikova@uohk.com

Yuliya O. Burtseva - Pedagogikos mokslų daktarè, rektorè, Administracijos katedra, Donetsko regiono pedagogų rengimo institutas, Kramatorskas, Ukraina.

El. paštas: yu.burtseva@tanu.pro 